\title{
Recent trends in fish feed ingredients - mini review
}

\author{
Norbert Révész", Janka Biró
}

NAIK Research Institute for Fisheries and Aquaculture, 35. Anna-liget str., Szarvas, Hungary

\begin{abstract}
This review has highlighted - without claiming to be exhaustive - the recent trends in fish feed ingredients, started with the problems of fish meal and fish oil. The possible alternatives were presented and evaluated as replacement of FM in finfish diets. Current alternative feed ingredients are complimentary. Feeds that include several ingredients are more balanced and reduced the ANFs of each separate ingredient, what leads to better growth rates and animal health. Currently, vegetable-based sources like soy are dominating issue of the fishmeal replacement. By high level of processing and using novel techniques the digestibility and nutrient availability can be enhanced. There is room, however, for certain novel ingredients, such as algae- and insect-based feeds to gain a larger share of feed ratios in aquaculture. Yeasts and their derivatives are used by choice as alternatives for antibiotics. Processing of wood raw materials into a protein-rich components are also very promising ingredients for fish feeds. Many times, we have to use pre- and probiotic compounds, feed additives to enhance the utilization, palatability of the alternative ingredients. Maintaining good health and welfare of fish is vital to be sustainable and cost effective.
\end{abstract}

Keywords: nutrition, alternative, ingredients, aquaculture

\section{INTRODUCTION}

Fish farming is commonly described as being extensive, semi-intensive or intensive. Continuous growing of aquaculture sector (around $8 \%$ per year) led systems to be more and more intensive. In intensive farming, the fish are kept at high stocking density, that's why the fish are dependent on the feed provided. Last decades aquaculture became more and more effective, but it has not been without concern for natural resource use, environmental impact and social judgement. Increasing fishmeal (FM) cost, irregular supply, decreasing availability, and poor quality of FM have put forward highlighting on its partial or complete substitution with other alternative protein sources. The fish feed industry has to be very responsible about to use FM alternatives. Scientists have to share on this burden to achieve sustainable, cost-effective aims. Indicators of sustainability in aquaculture could be energy efficiency, use of water, nutrient utilisation efficiency and production costs. The climate change is also affecting the sector, such as the predicted changes in ocean circulation pattern might also have a negative influence on the reliability of small pelagic stocks that being utilized for FM production. Appearance of mycotoxins or other dis- 
eases on terrestrial plants can affect negatively the potential alternative ingredients. Due to lots of investment and research in feed formulation promotion of non-marine ingredients resulted that these goods can provide the adequate nutrients for fish to achieve successful growth and still remain healthy. Significant progress has been made over the past decade in reducing levels of FM in commercial feeds for farmed fish. Some obstacles associated with plant-based protein diets are: amino acid imbalances and deficiencies, high levels of indigestible carbohydrates present in certain grain products, and varying antinutritive factors (ANFs) that negatively affect fish growth and health. Animal protein ingredients are also shown as possible replacements.

In this study the recent trends in alternative fish feed ingredients had been reviewed shortly. In conclusion, complete replacement of fishmeal in fish feeds is more difficult and will require further research efforts to achieve the expected goals, but there are many auspicious alternatives, what are illustrated here.

\section{History of fishmeal-based diets}

Fish meal and oil are easily digestible products used in fertilizers (López-Mosquera et al., 2011) and animal feed, ranging from livestock to aquaculture. Fish meal is a coarsely ground powder made from the cooked flesh of fish (Miles and Chapman, 2015). Though formerly important as a fertilizer, fish meal is now primarily used in animal feed. Certain species of oily fish, such as menhaden (Brevoortia and Ethmidium), anchovy (Engraulidae), herring (Clupeidae) and pilchard (Sardinae) are the main source of FM and its companion product, fish oil.

The first fish feed factories were established and started to developin the end of the $19^{\text {th }}$ century. In the 1940's, feed producers started to make complete semi-dry diet mixtures, what contained FM. They had problems with carry over disease contaminations, what effected fish stocks as well. Cooking extrusion is the most recent development in pelleted fish feed manufacture. These pellets are formed by extrusion of a moist mixture (20-24\%) followed by drying to reduce the moisture content to $10 \%$ or less. In the development of modern aquaculture, starting in the 1970s, FM and fish oil were key components of the feeds. These feeds are formulated nutritionally balanced to promote rapid growth, good health and welfare, according to the farmed species' needs.

Concerns are being raised about the negative consequences on world fishmeal production of overfishing, and negative effects caused by climate change (Soliman et al., 2017). Fish feed accounts could be over $50 \%$ of the total fish 
production cost (Rana et al., 2009). FM price in 2030 in real terms would increase by 29 \% (Figure 1) (OECD/FAO, 2017; The World Bank, 2013). If aquaculture consumes wild fish in the form of fishmeal and fish oil at higher amounts than what is produced, then aquaculture is a net consumer of fish, not a net producer, what is not sustainable (Hardy, 2010). Currently, a lot of studies have been conducted to assess the partial or complete substitution of FM in fish feeds (Kaushik et al., 1995; Montero et al., 2003 and 2005; Moutinho et al., 2017; Webster et al., 1992).

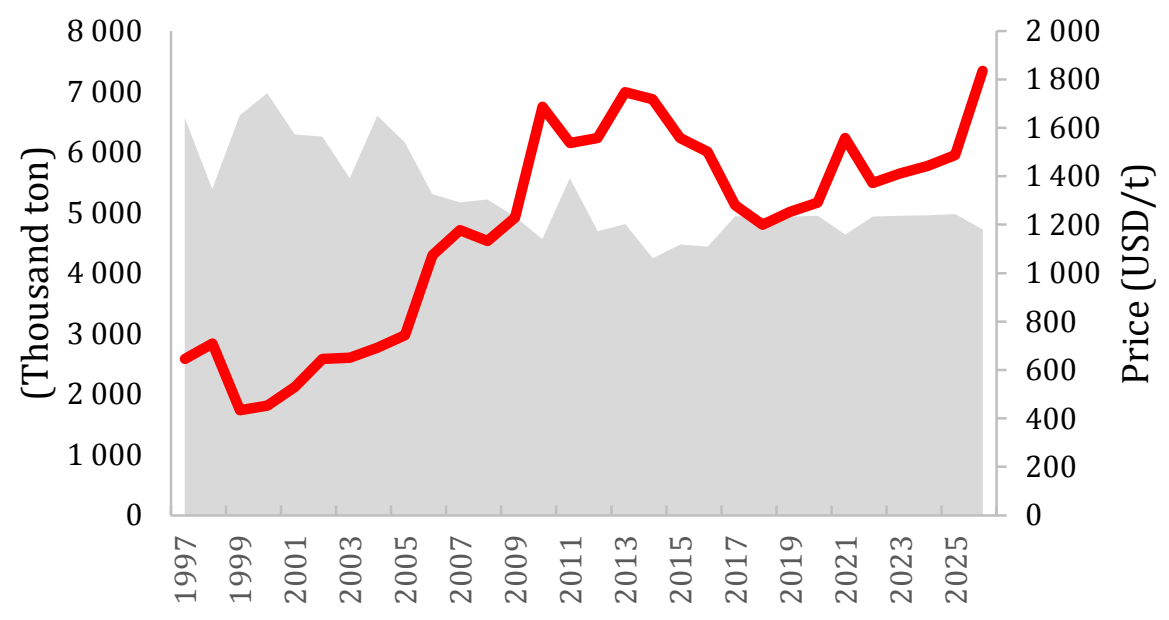

Figure 1. Prediction of worldwide Fish meal production (Source: OECD/FAO, 2017)

\section{Perspective fish feed alternative ingredients}

\section{Terrestrial plant products and by-products}

The most important protein supplements of plant origin are the oilseed meals, produced from the cake remaining after oil has been extracted from soybeans, cottonseed, canola, peanuts, sunflower seeds (Halver and Hardy, 2002). Plant protein sources with a low degree of processing are inexpensive and readily available, but their use for carnivorous fish is limited by the presence of starch and structural carbohydrates, and a wide variety of antinutritional factors (ANFs) (Øverland et al., 2009). The most dominant ANFs in terrestrial plant products are protease inhibitors, lectins, phytic acid, saponins, phytoestrogens, antivitamins, allergens, tannins, gossypol, glucosinolates (Francis et al., 2001). 
Currently soybean meal (SBM) is the most used alternative of fish meal due to its competitive nutrient composition, relatively good amino acid profile, easy accessibility and low price (Gatlin et al., 2007). However, SBM based diets causes in many fish species negative effects on digestibility, nutrient utilization, growth performance (Booman et al., 2018; Kaushik et al., 1995; Urán et al., 2008; Zhang et al., 2018). The ANFs in soybean meals caused enteritis in such cases (Knudsen et al., 2008; Krogdahl et al., 2015; Marković et al., 2016; Nayak, 2010; Sørensen et al., 2011). SBM has been the predominant form of soybean used and is available either as de-hulled ( $\sim 48 \%$ crude protein) or with hulls added ( $\sim 44 \%$ crude protein) (NRC, 2001).

Cottonseed meal (CSM) is a by-product of the cotton fiber and cottonseed oil industries. CSM has approximately $41.7 \%$ crude protein content and this is the third leading seed by weight used (Gatlin et al., 2007). However, the major problem associated with CSM use is the toxicity of the gossypol (Rinchard et al., 2002). On the other hand there are other concerns of CSM as a protein source, because of its low levels of lysine and methionine, and high crude fiber level (Cheng and Hardy, 2002b). In case of channel catfish (Ictalurus punctatus) researchers reported that gossypol is a strong natural antioxidant and had received much attention due to its biological activities, such as it improved immune responses and disease resistance (Yildirim et al., 2003).

Canola and rapeseed are both names on the plants Brassica napus and Brassica campestris. Canola meals, resulting from oil extraction processes, contains about $35 \%$ crude protein and 12\% crude fiber (Sørensen et al., 2011). Because of a relatively high content of crude fiber and phytate, canola has a limited use for carnivorous fish (Drew et al., 2007). The use of rapeseed meal as an animal feed is limited by the presence of ANFs (Davies et al., 1990).

Peanut meal (PM) is a by-product obtained from oil extraction of the whole or broken peanut seeds and it has variable chemical composition with an average content of $45.6 \%$ crude protein (Batal, et al., 2005). For many fish species PM is deficient in lysine (Lim, 1997). Peanuts often contaminated with the fungus, Aspergillis flavis, which produces aflatoxin (Bezerra da Rocha et al., 2014; Marroquín-Cardona et al., 2014; Richard, 2007).

Sunflower meal (SFM) is produced from the oil cake after oil extraction from dehulled sunflower seed. SFM is highly palatable for fish and it has low antinutritional factors (Sørensen et al., 2011). It has low levels of lysine and it has high levels of fibre (18-23\%) and lignin (Mérida et al., 2010). Sunflower meal showed good digestive utilization of protein, even though the digestible energy was low due to the carbohydrate fraction (Sanz et al., 1994). 
DDGS (Dried Distiller's Grain with Solubles), a by-product from bioethanol production, has high amounts of energy, medium protein $(\sim 30 \%)$, digestible fibre and accessible phosphorous enable the preparation of sustainable fish feeds with a high nutritional value (Gatlin et al., 2007). Moreover, DDGS has an additional advantage over other plant feed ingredients, namely its lack of ANFs (Makkar, 2012).

Protein concentrates from various sources such as soybean, pea, rapeseed, sunflower, as well as corn and wheat gluten can be competitive alternatives of fish meal (Collins et al., 2013; Escaffre et al., 1997; Øverland et al., 2009; Torstensen et al., 2011; Thiessen et al., 2004; Wu et al; 1995). These advanced products have reduced ANF content, increased digestibility than their origin plant.

\section{Micro and macro algae}

Algae can be differentiated (by the body size and structure) either to microalgae (with algal bodies that need microscope to be observed) or to macroalgae (large enough to be seen with unaided eye) (Yakoob et al., 2011). Microalgae can grow in both fresh and marine water as well as in almost every environmental condition on earth from frozen lands of Scandinavia to hot desert soils of the Sahara (Safi et al., 2014). Algae have been considered potentially viable alternative feed ingredients for aquaculture. Macro and micro algae have been used as dietary supplements to enhance the health and nutritional performance of a range of farmed fish species (Güroy et al., 2011). Algae have attractive properties as a candidate to replace meals, because they are rich in protein and carbohydrates, which are necessary components in human and animal diets. Algae also contain a high percentage of lipids, which are crucial in aquaculture diets (Table 1) (Maisashvili et al., 2015). Algae can produce a number of biomolecules including astaxanthin, lutein, beta-carotene, chlorophyll, phycobiliprotein, Polyunsaturated Fatty Acids (PUFAs), beta-1,3-glucan, and pharmaceutical and nutraceutical compounds (Yaakob et al., 2011). Omega 3-fatty acids like eicosapentanoic acid (EPA) and docosahexaenoic acid from microalgae have therapeutic importance. This is found in fish oil and microalgae. In microalgae it is found in the classes of Bacillariophceae (diatoms) Chlorophyceae, Chrysophyseae, Cryptophyceae, Eustigamatophyceae and Prasinophyceae. This product from algae is superior over fish oil in not having off flavors, is more pure, has a low cholesterol content and is inexpensive (Belarbi et al., 2000). The protein content of marine algae differs according to the species. Generally, it is low for brown seaweeds (3 - 15\% of dry weight), moderate for green algae ( 9 - 26\% of dry weight), and high for red seaweeds (maximum $47 \%$ of dry weight) (Fleurence, 1999). Thus, among the different species of 
macro algae, the red algae seems to be the most suitable source for animal nutrition because of their relatively high protein content and structurally diverse bioactive compounds with great pharmaceutical and biomedical potential (Fleurence et al., 2018).

\section{Table 1}

General composition of different algae (\% of dry matter)

\begin{tabular}{lccc}
\hline Species & Protein & Carbohydrates & Lipids \\
\hline Anabaena cylindrica & $43-56$ & $25-30$ & $4-7$ \\
Aphanizomenon flos-aquae & 62 & 23 & 3 \\
Chlamydomonas rheinhardii & 48 & 17 & 21 \\
Chlorella pyrenoidosa & 57 & 26 & 3 \\
Chlorella vulgaris & $51-58$ & $12-17$ & $14-22$ \\
Dunaliella salina & 57 & 32 & 6 \\
Euglena gracilis & $39-61$ & $14-18$ & $14-20$ \\
Porphyridium cruentum & $28-39$ & $40-57$ & $9-14$ \\
Scenedesmus obliquus & $50-56$ & $10-17$ & $12-14$ \\
Spirogyra sp. & $6-20$ & $33-64$ & $11-21$ \\
Arthrospira maxima & $60-71$ & $13-16$ & $6-7$ \\
Spirulina platensis & $46-63$ & $8-14$ & $4-9$ \\
Synechococcus sp. & 63 & 15 & 11 \\
\hline
\end{tabular}

Single cell proteins

The term single-cell protein (SCP) is used to describe protein derived from cells of microorganisms such as yeast, fungi, algae and bacteria which are grown on various carbon sources for synthesis (Ritala et al., 2017). The production of SCP has important advantages over other sources of proteins, such as its considerably shorter doubling time, the small land requirement, and the fact that it is not affected by the weather conditions (García-Garibay et al., 2015). Studies have shown that yeasts, like Saccharomyces cerevisiae, Candida utilis and Kluyveromyces marxianus have favourable amino acid composition and good protein source (40-50 \%) (Shurson, 2018). Besides this, yeasts have numerous beneficial effects on fish, such as these ingredients are improving weight gain, stimulating the antioxidant defence system and digestive enzymes (Carvalho et al., 1997; Kiron, 2012; Pohlenz and Gatlin, 2014). The common sources of $\beta$-glucan are derived from the cell wall of baker's yeast $S$. cerevisiae and the most important among all are $\beta-1,3$ and 1,6 glucan (Meena et al., 2013). The commonly used prebiotics, the mannanoligosaccharides (MOS) are 
also derived from S. cerevisae, what have beneficial effects on gut health (Merrifield et al., 2010).

Yeast derived from processing of low-value and non-food lignocellulosic biomass is a potential sustainable source of protein in fish diets (Kumar et al., 2008; Øverland and Skrede, 2017). SCP can be produced using the residual stream from the forest industry. This offers an attractive concept of turning forest raw material into a protein-rich component in fish feed (Alriksson et al., 2014). Microbes can be used to ferment some of the waste materials, such as vegetable and fruit wastes, food-processing wastes, and residues from alcohol production (Wadhwa and Bakshi, 2016).

\section{Animal by-products}

Animal by-products are derived from the meat-packing, poultry processing and rendering industries (Abdel-Warith et al., 2001). Since the bovine spongiform encephalopathy (BSE) crisis meat and bone meal (category 1-2) cannot be used as feed material. The protein content of these products after drying ranges from 50 to over 85\% (Halver and Hardy, 2002). These animal protein ingredients are good, but even not enough sufficient sources of amino acids with high protein content, total digestible dry matter and energy similar to fish meal, and besides this are comparatively less expensive (Badillo et al., 2014; Fowler, 1991; Sealey et al., 2011; Shapawi et al., 2007).

Processed animal protein (PAP) is a complete feed material with a high nutritional value produced from animal by-products (category 3), i.e. the part of animals (bones, offals, etc.) coming from non-ruminant animals controlled as fit for human consumption at the point of slaughter. Supplemented rendered animal protein for fish, can be an appropriate alternative protein source to replace partially the fishmeal (El-Sayed, 1998; Havasi et al., 2015; Kumar et al., 2016).

Poultry by-product meal (PBM) is also considered as proper replacement for FM. PBM has lower ash content such as FM, what is desirable in fish feeds, because it contributes to Phosphorous levels in fish farm effluents (Cheng and Hardy, 2002a). High inclusion of PBM is also able to reduce the growth performance (Nengas et al., 1999; Abdel-Wraith and Davies, 2001), but positive effects also had been reported (Yones and Metwalli, 2015).

Whole blood meal (WBM) and haemoglobin meal (HM) are very good protein sources (WBM 80\%; HM 95\%) with high level of lysine. High levels of histidine and low quantity of isoleucine may be limiting factors of blood meal inclusion $(N R C, 2011)$. Due to haemoglobin, the high iron content in blood meal 
limits inclusion, because of oxidation of astaxanthin and/or overload of iron in the fish (Rørvik et al., 2003; Sørensen et al., 2011).

Due to technological improvements feather meal became more and more digestible for fish with $\sim 77 \%$ crude protein, what made it to be alternative ingredient (Bureau et al., 2000; Davies et al., 2009; Sugiura et al., 1998).

\section{Insect meals}

About $70-75 \%$ of all animal species living on earth are insects and, together, they play an important role in recycling materials in the terrestrial biosphere (Katayama et al. 2008). They grow and reproduce easily, have high feed conversion efficiency (since they are poikilotherm) and can be reared on biowaste streams (Makkar et al., 2014). Their further benefit is that they could serve as a more environmentally friendly alternative for the production of animal protein from the perspective of greenhouse gases and $\mathrm{NH}_{3}$ emissions compared to the conventional livestock (Oonincx et al., 2010). However, the commercialisation of this resource has surprisingly just started in the last decade and is still in its very infancy (Tschirner and Kloas, 2017).

Insects' pupae, larvae, or adults can be consumed by other farm animals such chickens, cattle, fish, etc. (Katayama et al., 2008). One of the most intensively investigated species for fish feed production is Hermetia illucens (Diptera: Stratiomyidae) or Black Soldier Fly (BSF) (Henry et al., 2015; Rumpold et al., 2016; Tschirner and Kloas, 2017). Although insects generally present some characteristics that do not match with the fish meal, the amino acid profile of the Diptera shows that this group of insects could be a possible alternative protein source to be used in aquaculture (Barroso et al., 2014). Two other promising candidates in term of fish nutrition are mealworms and maggots (Henry et al., 2015).

From the nutritional point of view, depending on species and/or stage, insects are rich in protein and lipids; nevertheless, the presence of chitin a priori indicates a negative characteristic. However, chitin also is present in crustacean, which are widely consumed by fish (Barroso et al., 2014). Its potential as fish meal replacement is furthermore limited by its fatty acid composition that was of minor value compared to fish meal (Rumpold et al., 2016). This limitation could be reduced by supplementing the fly larvae with omega-3 fatty acids via fish offal (St-Hilaire et al., 2007). However, when insects (mealworm, maggots, BSF) were fed whole to fish, they usually compared positively with control fish usually fed low quality commercial pellets. The partial replacement with insect meal seems possible, mainly for herbivorous/omnivorous species, 
but also for some carnivorous fish (black carp (Mylopharyngodon piceus), rainbow trout (Oncorhynchus mykiss), Japanese sea bass (Lateolabrax japonicus), chum salmon (Oncorhynchus keta), gilthead seabream (Sparus aurata) and european seabass (Dicentrarchus labrax)) (Henry et. al., 2015).

Nevertheless, more studies are needed to know the digestibility, chitin content and digestive effect, presence of toxic, meal treatments (such as degreasing), adequate mixtures of different insect species or to modify the nutritional value of insects by changing their diet or rearing condition. The great variety of insect species, habitats, development stages, feeding habits and other characteristics most likely affects insect nutritional value and makes insect meal very interesting to study as an alternative to fish meal (Barroso et al., 2014).The palatability of the insect meals containing diets is good and that these alternate feed resources can replace soybean and fishmeal in the diets of livestock and fish species (Makkar et al., 2014).

Conventional selection index resulted huge benefit in past, animals were selected based on phenotypic variation. However after some period of time when the methodology reached its maximum potential new procedures became widespread.

Best Linear Unbiased Prediction (BLUP) is a method that substitutes conventional phenotypic measurements in the selection index. It is more precise and accurate in prediction genetic potential of animals, taking into consideration the relationships among the animal and the influencing environmental factors. BLUP allows comparing animals merit within different farm with different environment, which is impossible to do with conventional methods.

Economic methodology in constructing selection index is the method by which we evaluate the economic value of each trait and get so called economic weights. This coefficient can be used to calculate aggregated breeding value thus profit can be maximized in the procedure of selection.

\section{Acknowledgements}

The work of NR was made possible by the project called 'The specialise of the SZIU Campus of Szarvas research and training profile with intelligent specialization in the themes of water management, hydroculture, precision mechanical engineering, alternative crop production' [grant number EFOP-3.6.1-162016-00016]. 


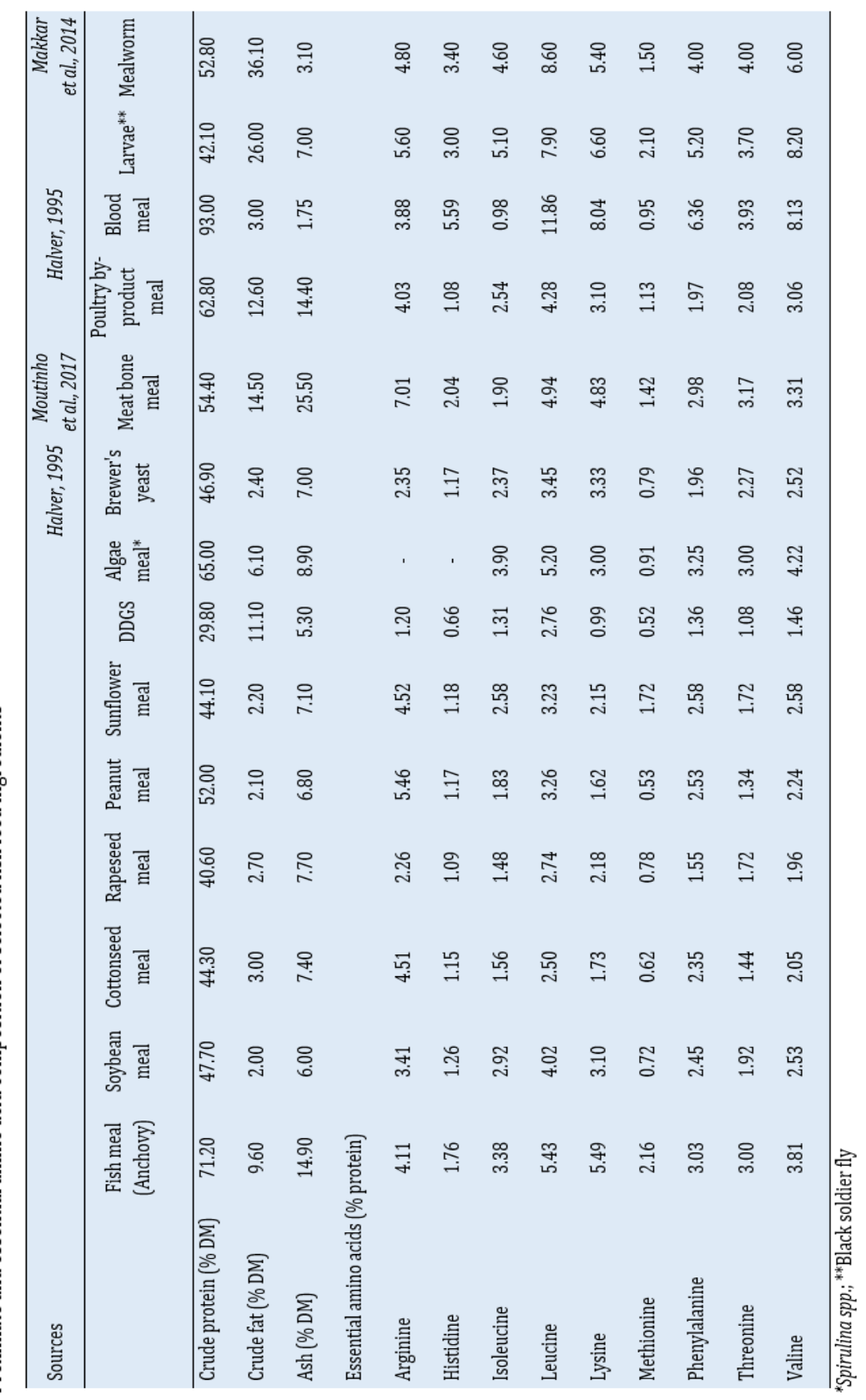




\section{REFERENCES}

Abdel-Warith, A. A., Russell, P. M., \& Davies, S. J. (2001). Inclusion of a commercial poultry by-product meal as a protein replacement of fish meal in practical diets for African catfish Clarias gariepinus (Burchell 1822). Aquaculture Research, 32 (Burchell 1822), 296-305. DOI: 10.1046/j.1355557x.2001.00053.x

Alriksson, B., Hörnberg, A., Eirikur Gudnason, A., Knobloch, S., Arnason, J., \& Johannsson, R. (2014). Fish Feed From Wood. Cellulose Chemistry and. Technology, 48 (910), 843-848. Retrieved from Link

Badillo, D., Herzka, S.Z., \& Viana, M.T., (2014). Protein Retention Assessment of Four Levels of Poultry By-Product Substitution of Fishmeal in Rainbow Trout (Oncorhynchus mykiss) Diets Using Stable Isotopes of Nitrogen ( $\mathrm{d} 15 \mathrm{~N}$ ) as Natural Tracers. PLOS One, 9, 1-8. DOI: 10.1371/journal.pone.0107523

Barroso, F. G., de Haro, C., Sánchez-Muros, M. J., Venegas, E., Martínez-Sánchez, A., \& Pérez-Bañón, C. (2014). The potential of various insect species for use as food for fish. Aquaculture, 422-423, 193201. DOI: 10.1016/j.aquaculture.2013.12.024

Batal, A., Dale, N., \& Café, M., (2005). Nutrient composition of peanut meal. Journal of Applied Poultry Research. 14, 254-257. DOI: 10.1093/japr/14.2.254

Belarbi, E.H., Molina, E., \& Chisti, Y., (2000). A process for high yield and scaleable recovery of high purity eicosapentaenoic acid esters from microalgae and fish oil. Enzyme and Microbial Technology. 26, 516-529. DOI: 10.1016/S0141-0229(99)00191-X

Bezerra da Rocha, M.E., Freire, F. da C.O., Erlan Feitosa Maia, F., Izabel Florindo Guedes, M., \& Rondina, D., (2014). Mycotoxins and their effects on human and animal health. Food Control 36, 159-165. DOI: 10.1016/j.foodcont.2013.08.021

Booman, M., Forster, I., Vederas, J.C., Groman, D.B., \& Jones, S.R.M., (2018). Soybean meal-induced enteritis in Atlantic salmon (Salmo salar) and Chinook salmon (Oncorhynchus tshawytscha) but not in pink salmon (O.gorbuscha). Aquaculture 483, 238-243. DOI: 10.1016/j.aquaculture.2017.10.025

Bureau, D.P., Harris, A.M., Bevan, D.J., Simmons, L.A., Azevedo, P.A., \& Cho, C.Y., (2000). Feather meals and meat and bone meals from different origins as protein sources in rainbow trout (Oncorhynchus mykiss) diets. Aquaculture 181, 281-291. DOI: 10.1016/S0044-8486(99)00232-X

Carvalho, a P., Escaffre, a, Teles, a 0., \& Bergot, P. (1997). First feeding of common carp larvae on diets with high levels of protein hydrolysates. Aquaculture International, 5, 361-367. DOI: 10.1023/A:1018368208323

Cheng, Z. J., \& Hardy, R. W. (2002a). Apparent digestibility coefficients and nutritional value of poultry by-product meals for rainbow trout (Oncorhynchus mykiss) measured in vivo using settlement. Journal of the World Aquaculture Society, 33, 458-465. DOI: 10.1016/s0044-8486(02)00260-0

Cheng, Z.J., \& Hardy, R.W., (2002b). Apparent digestibility coefficients and nutritional value of cottonseed meal for rainbow trout (Oncorhynchus mykiss). Aquaculture 212, 361-372. DOI: $\underline{10.1016 / S 0044-8486(02) 00260-0}$

Collins, S.A., Øverland, M., Skrede, A., \& Drew, M.D., (2013). Effect of plant protein sources on growth rate in salmonids: Meta-analysis of dietary inclusion of soybean, pea and canola/rapeseed meals and protein concentrates. Aquaculture 400-401, 85-100. DOI: 10.1016/j.aquaculture.2013.03.006

Davies, S.J., Gouveia, A., Laporte, J., Woodgate, S.L., \& Nates, S., (2009). Nutrient digestibility profile of premium (category III grade) animal protein by-products for temperate marine fish species (European sea bass, gilthead sea bream and turbot). Aquaculture Research. 40, 1759-1769. DOI: $\underline{10.1111 / j .1365-2109.2009 .02281 . x}$

Davies, S.J., McConnell, S., \& Bateson, R.I., (1990). Potential of rapeseed meal as an alternative protein source in complete diets for tilapia (Oreochromis mossambicus Peters). Aquaculture 87, 145-154. DOI: $\underline{10.1016 / 0044-8486(90) 90271-N}$ 
Drew, M.D., Borgeson, T.L., \& Thiessen, D.L., (2007). A review of processing of feed ingredients to enhance diet digestibility in finfish. Animal Feed Science Technology. 138, 118-136. DOI: 10.1016/j.anifeedsci.2007.06.019

El-Sayed, A.-F.M., (1998). Total replacement of fish meal with animal protein sources in Nile tilapia, Oreochromis niloticus (L.), feeds. Aquaculture Research. 29, 275-280. DOI: 10.1046/j.13652109.1998.00199.X

Escaffre, A.M., Zambonino Infante, J., Cahu, C.L., Mambrini, M., Bergot, P., \& Kaushik, S.J., (1997). Nutritional value of soy protein concentrate for larvae of common carp (Cyprinus carpio) based on growth performance and digestive enzyme activities. Aquaculture 153, 63-80. DOI: $\underline{10.1016 / S 0044-8486(97) 00010-0}$

Fleurence, J., (1999). Seaweed proteins: Biochemical, nutritional aspects and potential uses. Trends in Food Science and Technology. 10, 25-28. DOI: 10.1016/S0924-2244(99)00015-1

Fleurence, J., Morançais, M., \& Dumay, J., (2018). Seaweed proteins, Proteins in Food Processing. Elsevier Ltd. DOI: $10.1016 /$ B978-0-08-100722-8.00010-3

Fowler, L.G., (1991). Poultry by-product meal as a dietary protein source in fall chinook salmon diets. Aquaculture 99, 309-321. DOI: 10.1016/0044-8486(91)90251-2

Francis, G., Makkar, H.P.S., \& Becker, K., (2001). Antinutritional factors present in plant-derived alternate fish feed ingredients and their effects in fish, Aquaculture. DOI: 10.1016/S00448486(01)00526-9

Garcia-Garibay, M., Gomezi-Ruiz, L., \& Cruz-Guerrero, A. (2015). Single-cell protein. In Biochemical Engineering and Biotechnology (pp. 417-434). Elsevier. DOI: 10.1016/C2013-0-09819-2

Gatlin, D.M., Barrows, F.T., Brown, P., Dabrowski, K., Gaylord, T.G., Hardy, R.W., Herman, E., Hu, G., Krogdahl, Å., Nelson, R., Overturf, K., Rust, M., Sealey, W., Skonberg, D., Souza, E.J., Stone, D., Wilson, R., \&W Wurtele, E., (2007). Expanding the utilization of sustainable plant products in aquafeeds: A review. Aquaculture Research. 38, 551-579. DOI: 10.1111/j.1365-2109.2007.01704.X

Güroy, D., Güroy, B., Merrifield, D.L., Ergün, S., Tekinay, A.A., \& Yiğit, M., (2011). Effect of dietary Ulva and Spirulina on weight loss and body composition of rainbow trout, Oncorhynchus mykiss (Walbaum), during a starvation period. Journal of Animal Physiology and Animal Nutrition. 95, 320-327. DOI: 10.1111/j.1439-0396.2010.01057.x

Halver, J. E. (1995). Use of INFIC data base for amino acid requirement studies. Journal of Applied Ichthyology, 11(3-4), 129-140. DOI: 10.1111/j.1439-0426.1995.tb00014.X

Halver, J.E., \& Hardy, R.W., (2002). Fish Nutrition, 3rd ed. Academic Press. DOI: 10.1016/b978$\underline{012319652-1 / 50006-9}$

Hardy, R.W., (2010). Utilization of plant proteins in fish diets: Effects of global demand and supplies of fishmeal. Aquaculture Research. 41, 770-776. DOI: 10.1111/j.1365-2109.2009.02349.x

Havasi, M., Kumar, S., Nagy, Z., Pál, L., Beliczky, G., Bercsényi, M., \& Gál, D., (2015). Effect of total fish meal replacement with vegetal protein alone or combined with rendered animal protein on growth performance and tissue composition of european catfish (Silurus glanis L.). Israeli Journal of Aquaculture - Bamidgeh 67.

Henry, M., Gasco, L., Piccolo, G., \& Fountoulaki, E. (2015). Review on the use of insects in the diet of farmed fish: Past and future. Animal Feed Science and Technology, 203 (1), 1-22. DOI: 10.1016/j.anifeedsci.2015.03.001

Katayama, N., Ishikawa, Y., Takaoki, M., Yamashita, M., Nakayama, S., Kiguchi, K., Kok, R., Wada, H., \& Mitsuhashi, J. (2008). Entomophagy: A key to space agriculture. Advances in Space Research, 41(5), 701-705. DOI: 10.1016/j.asr.2007.01.027

Kaushik, S. J., Cravedi, J. P., Lalles, J. P., Sumpter, J., Fauconneau, B., \& Laroche, M. (1995). Partial or total replacement of fish meal by soybean protein on growth, protein utilization, potential estrogenic or 
antigenic effects, cholesterolemia and flesh quality in rainbow trout, Oncorhynchus mykiss. Aquaculture, 133 (3-4), 257-274. DOI: 10.1016/0044-8486(94)00403-B

Kiron, V. (2012). Fish immune system and its nutritional modulation for preventive health care. Animal Feed Science and Technology, 173 (1-2), 111-133. DOI: 10.1016/j.anifeedsci.2011.12.015

Knudsen, D., Jutfelt, F., Sundh, H., Sundell, K., Koppe, W., \& Frøkiær, H., (2008). Dietary soya saponins increase gut permeability and play a key role in the onset of soyabean-induced enteritis in Atlantic salmon (Salmo salar L.). British Journal of Nutrition. 100, 120-129. DOI: $\underline{10.1017 / S 0007114507886338}$

Krogdahl, A., Gajardo, K., Kortner, T.M., Penn, M., Gu, M., Berge, G.M., \& Bakke, A.M., (2015). Soya Saponins Induce Enteritis in Atlantic Salmon (Salmo salar L.). Journal of Agricultural and Food Chemistry. 63, 3887-3902. DOI: 10.1021/if506242t

Kumar, R., Singh, S., \& Singh, O. V. (2008). Bioconversion of lignocellulosic biomass: Biochemical and molecular perspectives. Journal of Industrial Microbiology and Biotechnology, 35 (5), 377-391. DOI: $\underline{10.1007 / s 10295-008-0327-8}$

Kumar, S., Sándor Zs, J., Nagy, Z., Fazekas, G., Havasi, M., Sinha, A.K., De Boeck, G., \& Gál, D., (2016). Potential of processed animal protein versus soybean meal to replace fish meal in practical diets for European catfish (Silurus glanis): growth response and liver gene expression. Aquaculture Nutrition. 1-11. DOI: 10.1111/anu.12487

Lim, C., (1997). Replacement of Marine Animal Protein with Peanut Meal in Diets for Juvenile White Shrimp, Penaeus vannamei. Journal of Applied Aquaculture. 7, 67-78. DOI: 10.1300/J028v07n03

López-Mosquera, M. E., Fernández-Lema, E., Villares, R., Corral, R., Alonso, B., \& Blanco, C. (2011). Composting fish waste and seaweed to produce a fertilizer for use in organic agriculture. Procedia Environmental Sciences, 9, 113-117. DOI: 10.1016/j.proenv.2011.11.018

Maisashvili, A., Bryant, H., Richardson, J., Anderson, D., Wickersham, T., \& Drewery, M., (2015). The values of whole algae and lipid extracted algae meal for aquaculture. Algal Research. 9, 133-142. DOI: $\underline{10.1016 / j . a l g a l .2015 .03 .006}$

Makkar, H. P. S., Tran, G., Heuzé, V., \& Ankers, P. (2014). State-of-the-art on use of insects as animal feed. Animal Feed Science and Technology, 197, 1-33. DOI: 10.1016/j.anifeedsci.2014.07.008

Marković, Z., Stanković, M., Rašković, B., Dulić, Z., Živić, I., \& Poleksić, V., (2016). Comparative analysis of using cereal grains and compound feed in semi-intensive common carp pond production. Aquaculture International. 24, 1699-1723. DOI: 10.1007/s10499-016-0076-Z

Marroquín-Cardona, A.G., Johnson, N.M., Phillips, T.D., \& Hayes, A.W., (2014). Mycotoxins in a changing global environment - A review. Food and Chemical Toxicology. 69, 220-230. DOI: $\underline{10.1016 / j . f c t .2014 .04 .025}$

Meena, D. K., Das, P., Kumar, S., Mandal, S. C., Prusty, A. K., Singh, S. K., ... \& Mukherjee, S. C. (2013). Betaglucan: An ideal immunostimulant in aquaculture (a review). Fish Physiology and Biochemistry, 39 (3), 431-457. DOI: 10.1007/s10695-012-9710-5

Mérida, S.N., Tomás-Vidal, A., Martínez-Llorens, S., \& Cedrá, M.J., (2010). Sunflower meal as a partial substitute in juvenile sharpsnout sea bream (Diplodus puntazzo) diets: Amino acid retention, gut and liver histology. Aquaculture 298, 275-281. D0I: 10.1016/j.aquaculture.2009.10.025

Merrifield, D. L., Dimitroglou, A., Foey, A., Davies, S. J., Baker, R. T. M., Bøgwald, J., ... \& Ringø, E. (2010). The current status and future focus of probiotic and prebiotic applications for salmonids. Aquaculture, 302(1-2), 1-18. DOI: 10.1016/j.aquaculture.2010.02.007

Miles R.D., \& Chapman F. (2015). The Benefits of Fish Meal in Aquaculture Diets. University of Florida IFAS Extension, (May 2006), 1-6. Retrieved from Link

Montero, D., Kalinowski, T., Obach, A., Robaina, L., Tort, L., Caballero, M. J., \& Izquierdo, M. S. (2003). Vegetable lipid sources for gilthead seabream (Sparus aurata): Effects on fish health. Aquaculture, 225(1-4), 353-370. DOI: $\underline{10.1016 / S 0044-8486(03) 00301-6}$ 
Montero, D., Robaina, L., Caballero, M. J., Ginés, R., \& Izquierdo, M. S. (2005). Growth, feed utilization and flesh quality of European sea bass (Dicentrarchus labrax) fed diets containing vegetable oils: A time-course study on the effect of a re-feeding period with a $100 \%$ fish oil diet. Aquaculture, $248(1-$ 4), 121-134. DOI: 10.1016/j.aquaculture.2005.03.003

Moutinho, S., Martínez-Llorens, S., Tomás-Vidal, A., Jover-Cerdá, M., Oliva-Teles, A., \& Peres, H. (2017). Meat and bone meal as partial replacement for fish meal in diets for gilthead seabream (Sparus aurata) juveniles: Growth, feed efficiency, amino acid utilization, and economic efficiency. Aquaculture, 468, 271-277. DOI: 10.1016/j.aquaculture.2016.10.024

Nayak, S.K., 2010. Role of gastrointestinal microbiota in fish. Aquaculture Research. 41, 1553-1573. DOI: $\underline{10.1111 / j .1365-2109.2010 .02546 . X}$

Nengas, I., Alexis, M. N., \& Davies, S. J. (1999). High inclusion levels of poultry meals and related byproducts in diets for gilthead seabream Sparus aurata L. Aquaculture, 179(1-4), 13-23. DOI: $\underline{10.1016 / S 0044-8486(99) 00148-9}$

NRC - Committee on the Nutrient Requirements of Fish and Shrimp. (2011). Nutrient Requirements of Fish and Shrimp, National Academies Press. DOI: 10.17226/13039

OECD/FAO. (2017). OECD-FAO Agricultural Outlook 2017-2026. Paris: OECD Publishing. Link

Oonincx, D. G. A. B., van Itterbeeck, J., Heetkamp, M. J. W., van den Brand, H., van Loon, J. J. A., \& van Huis, A. (2010). An exploration on greenhouse gas and ammonia production by insect species suitable for animal or human consumption. PLoS ONE, 5(12), 1-7. DOI: 10.1371/journal.pone.0014445

Øverland, M., \& Skrede, A., (2017). Yeast derived from lignocellulosic biomass as a sustainable feed resource for use in aquaculture. Journal of the Science of Food and Agriculture. 97, 733-742. DOI: $\underline{10.1002 / j s f a .8007}$

Øverland, M., Sørensen, M., Storebakken, T., Penn, M., Krogdahl, Å., \& Skrede, A., (2009). Pea protein concentrate substituting fish meal or soybean meal in diets for Atlantic salmon (Salmo salar)-Effect on growth performance, nutrient digestibility, carcass composition, gut health, and physical feed quality. Aquaculture 288, 305-311. DOI: 10.1016/j.aquaculture.2008.12.012

Pohlenz, C., \& Gatlin, D. M. (2014). Interrelationships between fish nutrition and health. Aquaculture, 431,111-117. DOI: 10.1016/j.aquaculture.2014.02.008

Rana, K. J., Siriwardena, S., \& Hasan, M. R. (2009). Impact of rising feed ingredient prices on aquafeeds and aquaculture production. FAO Fisheries and Aquaculture Technical Paper (Vol. 541).

Richard, J.L., (2007). Some major mycotoxins and their mycotoxicoses-An overview. International Journal of Food Microbiology. 119, 3-10. DOI: 10.1016/j.ijfoodmicro.2007.07.019

Rinchard, J., Mbahinzireki, G., Dabrowski, K., Lee, K.-J., Garcia-Abiado, M.-A., \& Ottobre, J., (2002). Effects of dietary cottonseed meal protein level on growth, gonad development and plasma sex steroid hormones of tropical fish tilapia Oreochromis sp. Aquaculture International. 10. DOI: $\underline{10.1023 / A: 1021379328778}$

Ritala, A., Häkkinen, S.T., Toivari, M., \& Wiebe, M.G., (2017). Single cell protein-state-of-the-art, industrial landscape and patents 2001-2016. Frontiers in Microbiology. 8. DOI: $\underline{10.3389 / \text { fmicb.2017.02009 }}$

Rørvik, K.A., Dehli, A., Thomassen, M., Ruyter, B., Steien, S.H., \& Salte, R. (2003). Synergistic effects of dietary iron and omega-3 fatty acid levels on survival of farmed Atlantic salmon, Salmo salar L., during natural outbreaks of furunculosis and cold water vibriosis. Journal of Fish Diseases. 26, 477485. DOI: $10.1046 / j .1365-2761.2003 .00482 . x$

Rumpold, B. A., Klocke, M., \& Schlüter, O. (2017). Insect biodiversity: underutilized bioresource for sustainable applications in life sciences. Regional Environmental Change, 17(5), 1445-1454. DOI: $\underline{10.1007 / s 10113-016-0967-6}$ 
Safi, C., Zebib, B., Merah, O., Pontalier, P.-Y., \& Vaca-Garcia, C. (2014). Morphology, composition, production, processing and applications of Chlorella vulgaris: A review. Renewable and Sustainable Energy Reviews. 35, 265-278. DOI: 10.1016/j.rser.2014.04.007

Sanz, A., Morales, A.E., de la Higuera, M., \& Gardenete, G., (1994). Sunflower meal compared with soybean meals as partial substitutes for fish meal in rainbow trout (Oncorhynchus mykiss) diets: protein and energy utilization. Aquaculture 128, 287-300. DOI: 10.1016/0044-8486(94)90318-2

Sealey, W.M., Hardy, R.W., Barrows, F.T., Pan, Q., \& Stone, D.A.J., (2011). Evaluation of 100\% Fish Meal Substitution with Chicken Concentrate, Protein Poultry By-Product Blend, and Chicken and Egg Concentrate on Growth and Disease Resistance of Juvenile Rainbow Trout, Oncorhynchus mykiss. Journal of the World Aquaculture Society. 42, 46-55. DOI: 10.1111/j.1749-7345.2010.00442.x

Shapawi, R., Ng, W.K., \& Mustafa, S. (2007). Replacement of fish meal with poultry by-product meal in diets formulated for the humpback grouper, Cromileptes altivelis. Aquaculture 273, 118-126. DOI: 10.1016/j.aquaculture.2007.09.014

Shurson, G. C. (2018). Yeast and yeast derivatives in feed additives and ingredients: Sources, characteristics, animal responses, and quantification methods. Animal Feed Science and Technology, 235, 6076. DOI: $10.1016 /$ j.anifeedsci.2017.11.010

Soliman, N. F., Yacout, D. M. M., \& Hassaan, M. A. (2017). Responsible Fishmeal Consumption and Alternatives in the Face of Climate Change. International Journal of Marine Sciences, 7 (15), 130-140. DOI: $10.5376 /$ ijms.2017.07.0015

Sørensen, M., Berge, G.M., Thomassen, M., Ruyter, B., Hatlen, B., \& Ytrestøyl, T. (2011). Today's and tomorrow's feed ingredients in Norwegian aquaculture. ISBN: 9788272519437

Sørensen, M., Penn, M., El-Mowafi, A., Storebakken, T., Chunfang, C., Øverland, M., \&D Krogdahl, Å. (2011). Effect of stachyose, raffinose and soya-saponins supplementation on nutrient digestibility, digestive enzymes, gut morphology and growth performance in Atlantic salmon (Salmo salar, L). Aquaculture 314, 145-152. DOI: 10.1016/j.aquaculture.2011.02.013

St-Hilaire, S., Cranfill, K., McGuire, M. A., Mosley, E. E., Tomberlin, J. K., Newton, L., ... \& Irving, S. (2007). Fish Offal Recycling by the Black Soldier Fly Produces a Foodstuff High in Omega-3 Fatty Acids. Journal of the World Aquaculture Society, 38(2), 309-313. DOI: 10.1111/j.1749-7345.2007.00101.x

Sugiura, S.H., Dong, F.M., Rathbone, C.K., \& Hardy, R.W., (1998). Apparent protein digestibility and mineral availabilities in various feed ingredients for salmonid feeds. Aquaculture 159, 177-202. DOI: $\underline{10.1016 / S 0044-8486(97) 00177-4}$

The World Bank. (2013). Fish to 2030: Prospects for fisheries and aquaculture. Agriculture and Environmental Services, 3 (83177), 1-102.

Thiessen, D.L., Maenz, D.D., Newkirk, R.W., Classen, H.L., \& Drew, M.D., (2004). Replacement of fishmeal by canola protein concentrate in diets fed to rainbow trout (Oncorhynchus mykiss). Aquaculture Nutrition. 10, 379-388. DOI: 10.1111/j.1365-2095.2004.00313.x

Torstensen, B.E., Espe, M., Stubhaug, I., \& Lie, Ø. (2011). Dietary plant proteins and vegetable oil blends increase adiposity and plasma lipids in Atlantic salmon (Salmo salar L.). British Journal of Nutrition. 106, 633-47. DOI: $10.1017 /$ S0007114511000729

Tschirner, M., \& Kloas, W. (2017). Increasing the sustainability of aquaculture systems: Insects as alternative protein source for fish diets. Gaia, 26(4), 332-340. DOI: 10.14512/gaia.26.4.10

Urán, P.A., Gonçalves, A.A., Taverne-Thiele, J.J., Schrama, J.W., Verreth, J.A.J., \& Rombout, J.H.W.M., (2008). Soybean meal induces intestinal inflammation in common carp (Cyprinus carpio L.). Fish Shellfish Immunology. 25, 751-760. DOI: $10.1016 /$ i.fsi.2008.02.013

Wadhwa, M., \& Bakshi, M. P. S. (2016). Application of Waste-Derived Proteins in the Animal Feed Industry. Protein Byproducts: Transformation from Environmental Burden Into Value-Added Products. Elsevier Inc. DOI: 10.1016/B978-0-12-802391-4.00010-0 
Webster, C. D., Yancey, D. H., \& Tidwell, J. H. (1992). Effect of partially or totally replacing fish meal with soybean meal on growth of blue catfish (Ictalurus furcatus). Aquaculture, 103(2), 141-152. DOI: $\underline{10.1016 / 0044-8486(92) 90408-D}$

Wu, Y.V., Rosati, R.R., Sessa, D.J., \& Brown, P.B., (1995). Evaluation of Corn Gluten Meal as a Protein Source in Tilapia Diets. Journal of Agricultural Food Chemistry. 43, 1585-1588. DOI: $\underline{10.1021 / j f 00054 a 032}$

Yaakob, Z., Ali, E., Zainal, A., Mohamad, M., \& Takriff, M. S. (2014). An overview: Biomolecules from microalgae for animal feed and aquaculture. Journal of Biological Research (Greece), 21 (1), 1-10. DOI: $\underline{10.1186 / 2241-5793-21-6}$

Yildirim, M., Lim, C., Wan, P.J., \& Klesius, P.H. (2003). Growth performance and immune response of channel catfish (Ictalurus puctatus) fed diets containing graded levels of gossypol-acetic acid. Aquaculture 219, 751-768. DOI: 10.1016/S0044-8486(03)00062-0

Yones, A., \& Metwalli, A. (2015). Effects of Fish Meal Substitution with Poultry By-product Meal on Growth Performance, Nutrients Utilization and Blood Contents of Juvenile Nile Tilapia (Oreochromis niloticus). Journal of Aquaculture Research \& Development, 07 (01), 1-6. DOI: $\underline{10.4172 / 2155-9546.1000389}$

Zhang, C., Rahimnejad, S., Wang, Y. ru, Lu, K., Song, K., Wang, L., \& Mai, K. (2018). Substituting fish meal with soybean meal in diets for Japanese seabass (Lateolabrax japonicus): Effects on growth, digestive enzymes activity, gut histology, and expression of gut inflammatory and transporter genes. Aquaculture, 483, 173-182. DOI: 10.1016/j.aquaculture.2017.10.029 